\title{
DENSIFICATION OF SNOW ON THE ICE SHEET OF ELLSWORTH LAND AND THE SOUTHERN ANTARGTIG PENINSULA
}

\author{
By John C. Behrendt \\ (U.S. Geological Survey, Denver, Colorado, U.S.A.)
}

\begin{abstract}
Density-depth curves constructed from seismic travel-time data observed at 25 locations, show a large variation over an essentially isothermal area $\left(T=-22 \pm 2 \cdot 6^{\circ} \mathrm{C}\right)$. This is correlated with the wide range of mean annual accumulation values $\left(A=20\right.$ to $50 \mathrm{~g} . / \mathrm{cm} .^{2} \mathrm{yr}$. $)$. Quantitative estimates of mean annual accumulation can be obtained from seismic refraction data in this area by the expression $A=23 \cdot 5+0 \cdot 049\left(3500-V_{200}\right)$ where $V_{200}$ is the compressional wave velocity (m./sec.) observed at $200 \mathrm{~m}$. from the shot point. The density-depth curves can be used to give estimates of accumulation by the expression:
\end{abstract}

$$
A=2 \cdot 36\left(0 \cdot 9^{1} 3-\rho_{40}\right)
$$

where $\rho_{4}$ o is the density (g./ $/ \mathrm{cm} .3$ ) at $40 \mathrm{~m}$. depth. The internal consistency of these methods is indicated by the standard deviation of $\pm 2.9 \mathrm{~g} . / \mathrm{cm} .^{2} \mathrm{yr}$. for comparisons of accumulation estimates. The theoretical basis
for these results is discussed.

RÉsumé. Densification de la neige sur l'indlandsis d'Ellsworth Land et le sud de l'Antarctic Peninsula. Les courbes des densités en fonction des profondeurs construites à partir des temps de parcours sismiques observés en 25 stations, montrent une importante variation pour une zône pratiquement isotherme $\left(T=-22 \pm 2,6^{\circ} \mathrm{C}\right)$. Ceci est en rapport avec le grand écart des valeurs moyennes des accumulations annuelles $\left(A=20^{-} 5^{\circ}\right.$ g. $/ \mathrm{cm}^{2}$ an). Des estimations quantitatives d'accumulation moyenne annuelle peuvent être obtenues a partir de données de réfraction sismique dans cette zone par l'expression $A=23,5+0,049\left(3500-V_{200}\right)$ ou $V_{200}(\mathrm{~m} / \mathrm{s})$ est la vitesse de l'onde de compression observée à $200 \mathrm{~m}$ du point de tir. La courbe des densités en fonction des profondeurs peut être utilisée pour donner des estimations d'accumulations par l'expression
suivante;

$$
A=2,36\left(0,9^{1} 3-\rho_{40}\right)
$$

dans laquelle $\rho_{40}$ est la densité a $40 \mathrm{~m}$ de profondeur. La cohérence intrinsèque de ces méthodes est indiquée par un écart standard de $\pm 2,9 \mathrm{~g} . / \mathrm{cm} .^{2}$ an pour des comparaisons de l'estimation de l'accumulation. La base théorique concernant ces résultats est discutée.

Zusammenfassung. Verdichtung des Schnees auf dem Eisschild von Ellsworth Land und im Süden der Antarctic Peninsula. Dichte-Tiefen-Diagramme, abgeleitet aus seismischen Laufzeitbeobachtungen an 25 Stellen, zeigen starke Unterschiede innerhalb eines im wesentlichen isothermen Gebietes $\left(\mathcal{T}=-22 \pm 2,6^{\circ} \mathrm{C}\right)$. Diese Tatsache steht mit der starken Streuung der Werte für die mittlere Jahresakkumulation $(A=20-50$ $\mathrm{g} / \mathrm{cm}^{2} \mathrm{Jahr}$ ) in Zusammenhang. Zahlenmässig kann die mittlere Jahresakkumulation aus seismischen Refraktionswerten in diesem Gebiet mit der Formel $A=23,5+0,049\left(3500-V_{200}\right)$ abgeschätzt werden, worin $V_{200}$ die Geschwindigkeit $(\mathrm{m} / \mathrm{sec})$ der Druckwellen in $200 \mathrm{~m}$ Abstand vom Schusspunkt bedeutet. Auch die Dichte-Tiefen-Kurven können zur Abschätzung der Akkumulation herangezogen werden, und zwar nach einer der folgenden Formel:

$$
A=2,36\left(0,913-\rho_{4}\right)
$$

worin $\rho_{40}$ die Dichte in $40 \mathrm{~m}$ Tiefe bedeutet. Die innere Übereinstimmung zwischen diesen Methoden kann aus dem mittleren Fehler von $\pm 2,9 \mathrm{~g} / \mathrm{cm}^{2}$ Jahr beurteilt werden, der sich aus dem Vergleich von Akkumulationsabschätzungen ergibt. Die theoretischen Grundlagen dieser Ergebnisse werden diskutiert.

\section{INTRODUCTION}

During the austral summer of $196 \mathrm{I}-62$ a seven-man party carried out geophysical and glaciological investigations on the $1,700 \mathrm{~km}$. Antarctic Peninsula traverse in Ellsworth Land and the southern Antarctic Peninsula. Figures I and 2 show the area studied. Seismic measurements of ice thickness were made at 25 locations (Table I and Fig. 2) as discussed by Behrendt (1963). Velocity-depth curves were constructed by a method of numerical integration (Slichter, I932) using the time and distance data for the refracted compressional waves traveling through the snow. A continuous velocity increase with depth was assumed to the depth where maximum velocity is reached (about $150 \mathrm{~m}$. in this area).

From these velocity-depth curves, density-depth curves were constructed using the empirical expression Robin ( $195^{8}$, p. 88) showed to be valid below depths of ${ }_{5} \mathrm{~m}$. :

$$
\rho=2 \cdot 2 \mathrm{I} \times \mathrm{IO}^{-4}(\mathrm{I}-0 \cdot 0006 \mathrm{I} T)^{-\mathrm{I}} V_{\mathrm{p}}+0 \cdot 059
$$


where $\rho$ is the density in $\mathrm{g} . / \mathrm{cm} .^{3}, V_{\mathrm{p}}$ is the compressional wave velocity in $\mathrm{m} . / \mathrm{sec}$., and $T$ is the temperature in ${ }^{\circ} \mathrm{C}$. Figures $3^{-7}$ show the results of these calculations using the temperatures at $\mathrm{r}$ m. (from H. Shimizu personal communication). The variations in these curves are probably the result of the wide range in annual accumulation values (20 to $50 \mathrm{~g} . / \mathrm{cm} .{ }^{2} \mathrm{yr}$.) since the standard deviation of the mean annual (1o m.) temperatures is only $\pm 2.6^{\circ} \mathrm{C}$. from the average of $-22^{\circ} \mathrm{C}$. This suggested a method of determining quantitative estimates of mean annual accumulation from the seismic data.

Table I. Accumulation Determined from Seismic Data and Near-Surface Glaciology

\begin{tabular}{|c|c|c|c|c|c|}
\hline Station & $\begin{array}{c}A_{\mathrm{L}} \text { from } \rho \\
\text { at } h=4^{\circ} \mathrm{m}\end{array}$ & $\begin{array}{c}A_{\mathrm{C}} \text { from } \rho \\
\text { at } h=40 \mathrm{~m}\end{array}$ & $\begin{array}{c}A_{\mathrm{V}} \text { from } V_{\mathrm{p}} \\
\text { at } X=200 m .\end{array}$ & $\begin{array}{l}\text { Mean seismic } \\
\text { accumulation }\end{array}$ & $\begin{array}{c}\text { Measured } \\
\text { accumulation }\end{array}$ \\
\hline 224 & g. $/ \mathrm{cm}_{47}^{2} \mathrm{yr}$. & $\begin{array}{c}\text { g. } / \mathrm{cm}^{2} \mathrm{yr} . \\
4^{8}\end{array}$ & $\begin{array}{c}\text { g. } / \mathrm{cm}^{2} \text { yr. } \\
49\end{array}$ & g. $/ \mathrm{cm}_{4}^{2} \mathrm{yr}$. & g. $/ \mathrm{cm}^{2} \mathrm{yr}$. \\
\hline 256 & 44 & $4^{2}$ & 44 & 43 & $4^{8}$ \\
\hline 288 & $4^{I}$ & 39 & 45 & 42 & - \\
\hline $3^{20}$ & 43 & $4^{I}$ & 40 & $4 \mathrm{I}$ & - \\
\hline $35^{2}$ & 44 & 43 & 46 & 44 & - \\
\hline $3^{82}$ & 37 & 34 & 33 & 32 & - \\
\hline 404 & 44 & 43 & 37 & 31 & - \\
\hline 432 & 40 & 42 & 34 & 39 & 40 \\
\hline 464 & 24 & 28 & 23 & 24 & - \\
\hline 496 & 37 & 34 & 36 & 36 & 26 \\
\hline 528 & 35 & 32 & 43 & 37 & - \\
\hline 604 & $3^{8}$ & 35 & 37 & 37 & 46 \\
\hline 636 & 39 & 37 & $4^{2}$ & 39 & 34 \\
\hline 668 & $3^{8}$ & 36 & $4^{I}$ & 38 & $4^{I}$ \\
\hline 700 & 40 & 38 & 39 & 39 & 45 \\
\hline 732 & 47 & 49 & 47 & $4^{8}$ & 50 \\
\hline 764 & $5^{0}$ & 57 & $5^{1}$ & 53 & 48 \\
\hline 796 & 37 & 34 & 37 & 39 & - \\
\hline 840 & 28 & 28 & 27 & 28 & 28 \\
\hline 864 & 24 & 27 & 23 & 24 & - \\
\hline 908 & 29 & 28 & 30 & 29 & - \\
\hline 940 & 23 & 27 & 25 & 25 & 20 \\
\hline 976 & 40 & 37 & 43 & 40 & - \\
\hline 1008 & 36 & 33 & $3^{2}$ & 33 & 35 \\
\hline 1028 & 35 & 35 & 24 & $3^{1}$ & \\
\hline
\end{tabular}

* Personal communication from H. Shimizu.

\section{Discussion}

Pit measurements of accumulation values for twelve stations (Table I), furnished the author by Shimizu, were used with a value for "Eights" station determined from one season's observed snow accumulation. Figure 8 is a graph of accumulation $A$ versus the density $\rho$ at $40 \mathrm{~m}$. depth. The straight line shown was fitted by least squares to the data and the standard deviation of the points is $\pm 4.7 \mathrm{~g} . / \mathrm{cm} .^{2} \mathrm{yr}$. in terms of accumulation. This graph shows an inverse relation between accumulation and the density at $40 \mathrm{~m}$. at this relatively constant temperature.

Another empirical study was carried out using the velocity vs. distance curves constructed directly from the travel-time curves. Figures 9-I I compare accumulation with compressional wave velocities recorded at distances of 50 , 100 , and $200 \mathrm{~m}$. from the shot point, respectively. Assuming linear relationships for these graphs also, the standard deviations in terms of measured accumulations from the least-square straight lines are $\pm 6 \cdot 0 \mathrm{~g} . / \mathrm{cm} .{ }^{2} \mathrm{yr} ., 5 \cdot 8 \mathrm{~g} . / \mathrm{cm} .{ }^{2} \mathrm{yr}$., and $\pm 4.5 \mathrm{~g} . / \mathrm{cm} .^{2} \mathrm{yr}$. for $50, \mathrm{roo}$, and $200 \mathrm{~m}$. distances respectively. The depths $h$ corresponding to the velocities at each of these distances $X$ were measured and averaged from the velocitydepth curves with the following results: $X=5^{\circ} \mathrm{m} ., h=$ I I m., with standard deviation 


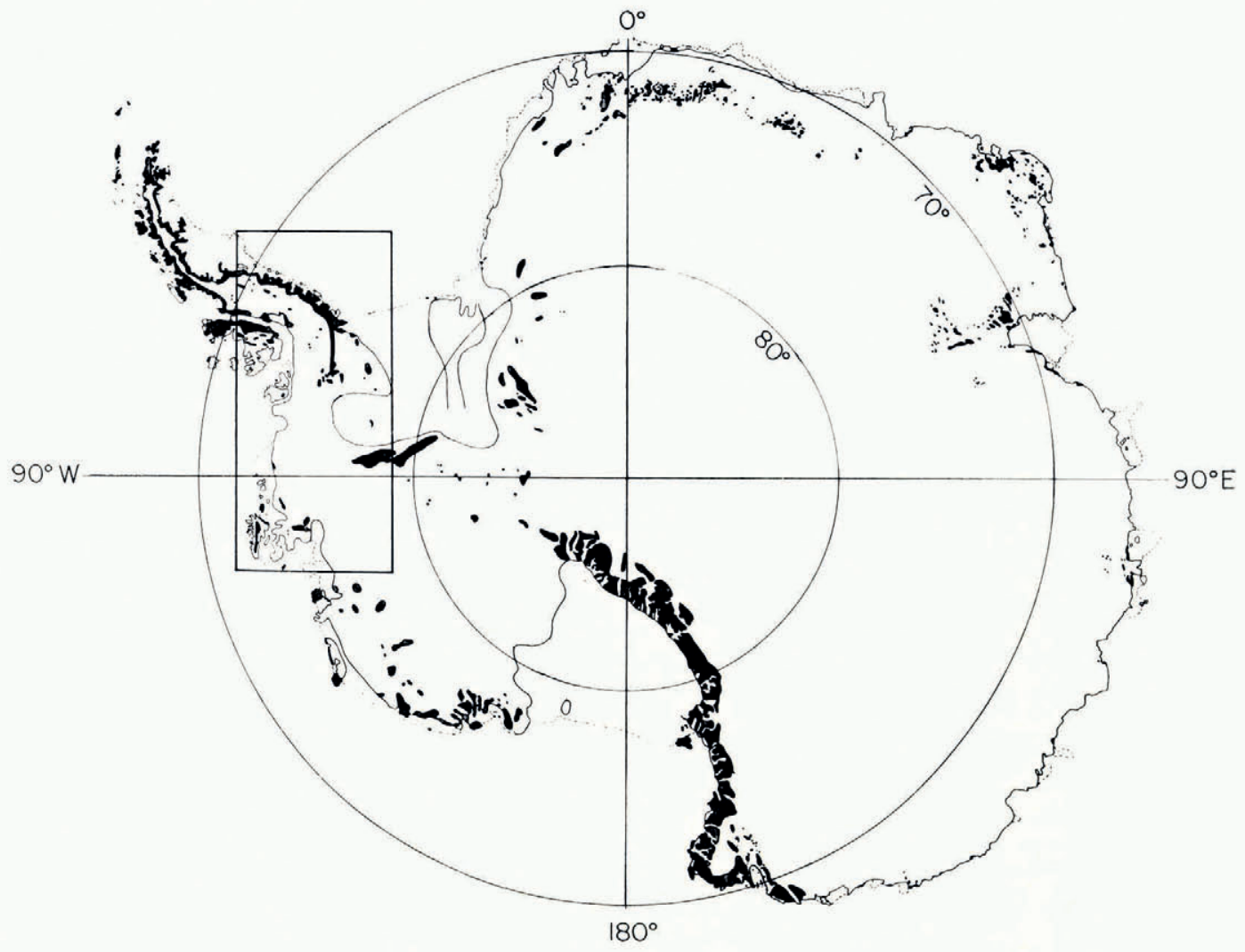

Fig. I. Map of Antarctica showing area studied

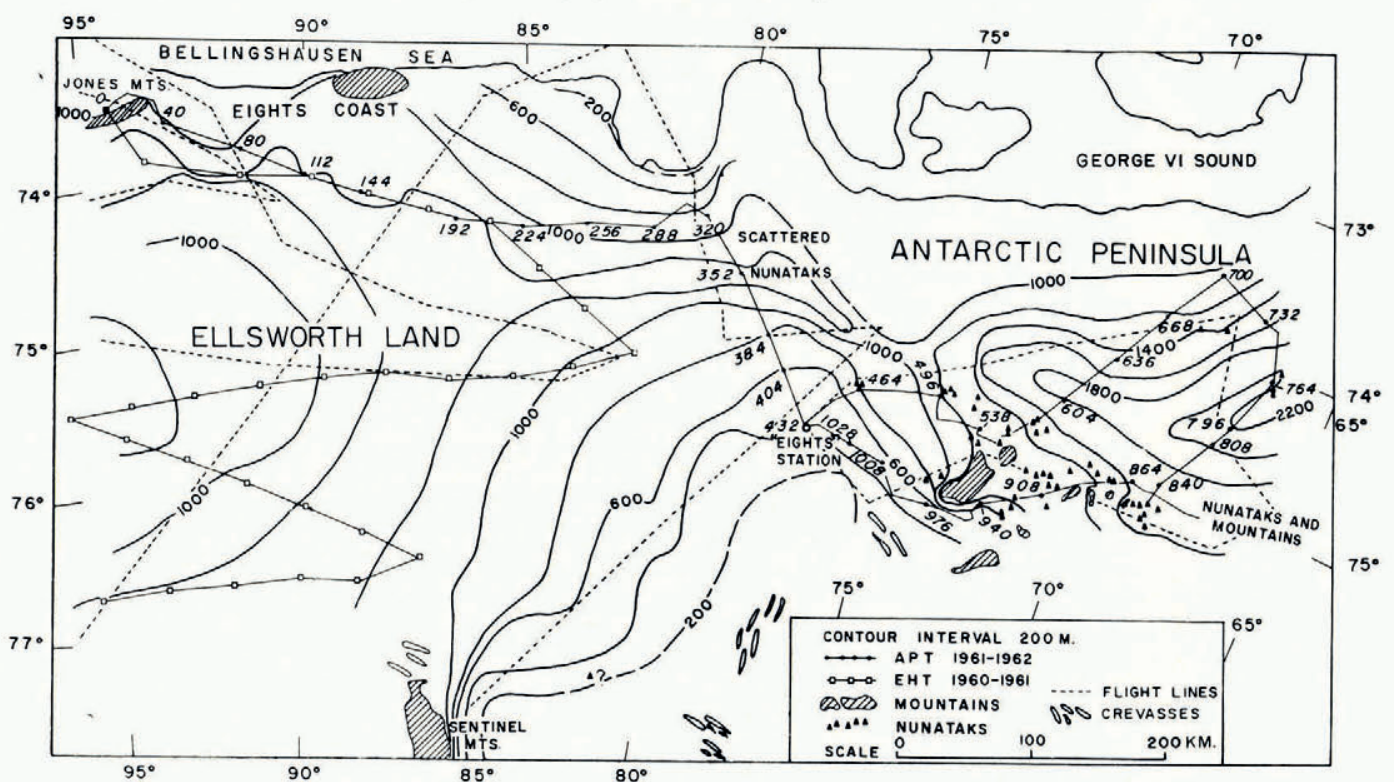

Fig. 2. Surface elevation map showing location of major stations (from Behrendt, 1963) 
$s= \pm 3.3 \mathrm{~m} . ; X=$ roo m., $h=2 \mathrm{I} \mathrm{m} ., s= \pm 4.2 \mathrm{~m}$; and $X=200 \mathrm{~m} ., h=4 \mathrm{I} \mathrm{m} ., s=$ $\pm 2 \cdot 7 \mathrm{~m}$. The least scatter from the straight lines was for $X=200 \mathrm{~m}$. (Fig. I I) corresponding to a mean depth of $4 \mathrm{I} \mathrm{m}$; t this is essentially equivalent to Figure 8 for accumulation versus density at $40 \mathrm{~m}$. depth.

I attempted an explanation of these empirical results on a theoretical basis. Bader ( 1962 ) and Landauer (1957) gave the following relations for the rate of snow densification $(-v)$ :

$$
\begin{aligned}
-v & =\frac{\mathrm{I}}{\rho} \frac{d \rho}{d t}=c \sinh \left(\sigma / \sigma_{\mathrm{o}}\right), \\
\sigma & =A t
\end{aligned}
$$

where $t$ is the time, $\sigma$ the load in $\mathrm{g} . / \mathrm{cm} \cdot{ }^{2}=\bar{\rho} h$ where $\bar{\rho}$ is the average density from the

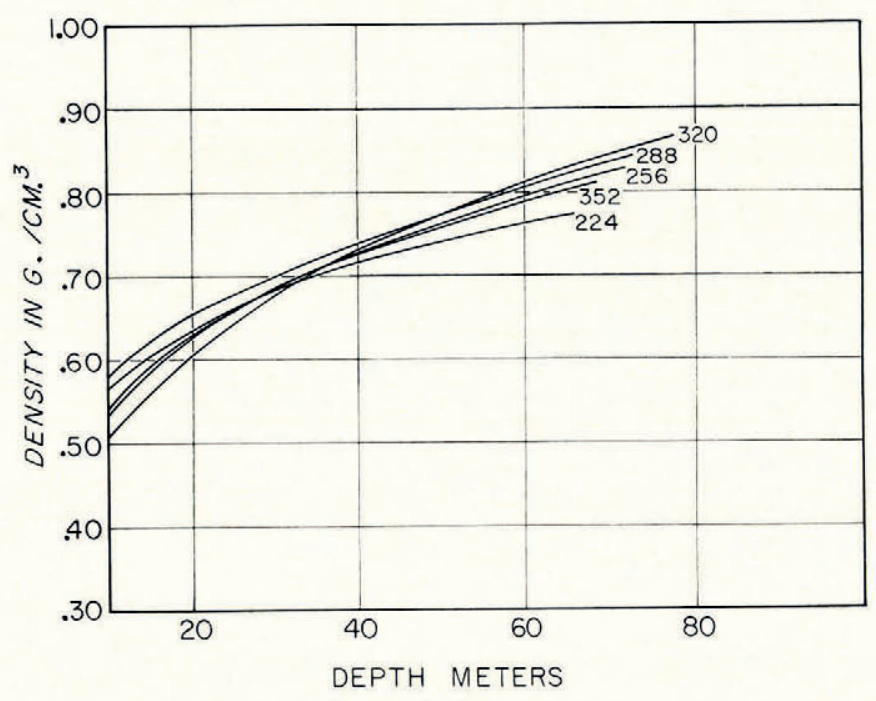

Fig. 3. Density-depth curves stations 224-320

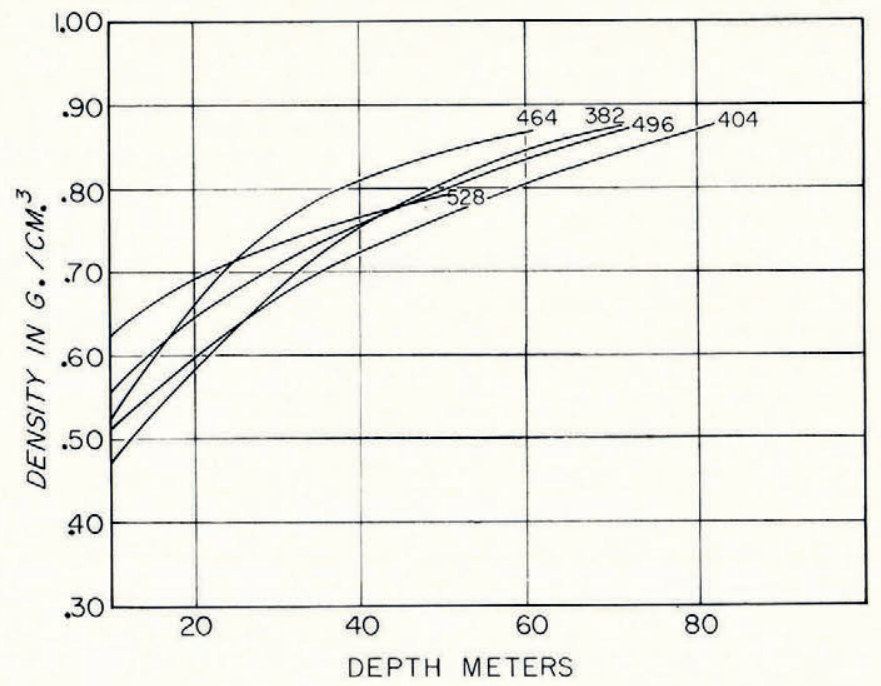

Fig. 4. Density-depth curves stations $3^{82-528}$ 
surface to a depth $h, \sigma_{\mathrm{o}}=700 \mathrm{~g} \cdot / \mathrm{cm} .^{2}$; and $c$ is a constant depending on snow type and temperature. Thus

$$
d \rho / \rho=c \sinh \left(A t / \sigma_{\mathrm{o}}\right) d t .
$$

Integrating and rearranging gives

$$
\ln \rho=c\left(\sigma_{\mathrm{o}} / A\right) \cosh \left(\sigma / \sigma_{\mathrm{o}}\right)+k
$$

where $k$ is a constant of integration. In the following discussion, I assumed $k$ was also constant throughout the area studied. Using the $2 \mathrm{~m}$. pit density data furnished by Shimizu and the density-depth curves of Figures $3-7$, values of $\sigma$ at $40 \mathrm{~m}$. depth were calculated for each of

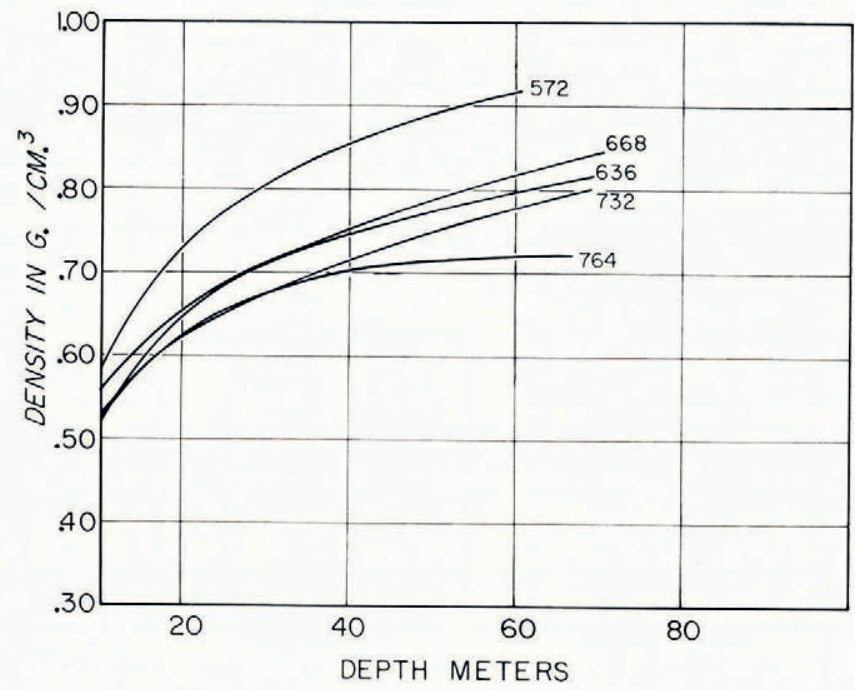

Fig. 5. Density-depth curves stations $57^{2-764}$

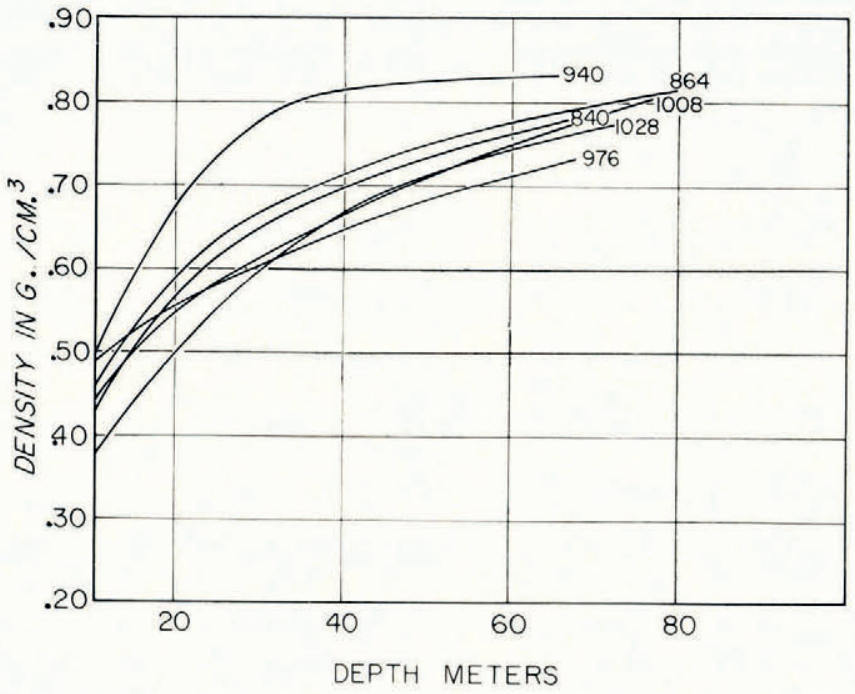

Fig. 6. Density-depth curves stations $84^{0-1028}$ 
the thirteen stations of Figure 8 by numerical integration. These were found to show the following apparently linear relation with $\rho$ at $40 \mathrm{~m}$. depth (Fig. 12):

$$
\bar{\rho}=0.54 \rho+0 \cdot 2 \text { I } 5 \text {. }
$$

Using this expression introduced an error of \pm 0.9 per cent in $\bar{\rho}$. Within the range of densities of Figure 8

or

$$
\begin{array}{r}
\mathrm{I} / \rho=-\mathrm{I} .445 \ln \rho+0.919 \\
\ln \rho=0.636-0.692 / \rho
\end{array}
$$

with an introduced error \pm 0.4 per cent in $\mathrm{I} / \rho$. (The error introduced by the assumption a linear relation between $\mathrm{I} / \rho$ and $\ln \rho$ is less than that between $\rho$ and $\ln \rho$ in the density range from 0.7 to $0.8 \mathrm{~g} . / \mathrm{cm}^{3}$.) From equation (6) and the relationship $\sigma=\bar{\rho} \mathrm{h}$, a theoretical curve of $\cosh \left(\sigma / \sigma_{\mathrm{o}}\right)$ versus $\ln \rho$ was calculated and plotted on a graph of the observed data in Figure

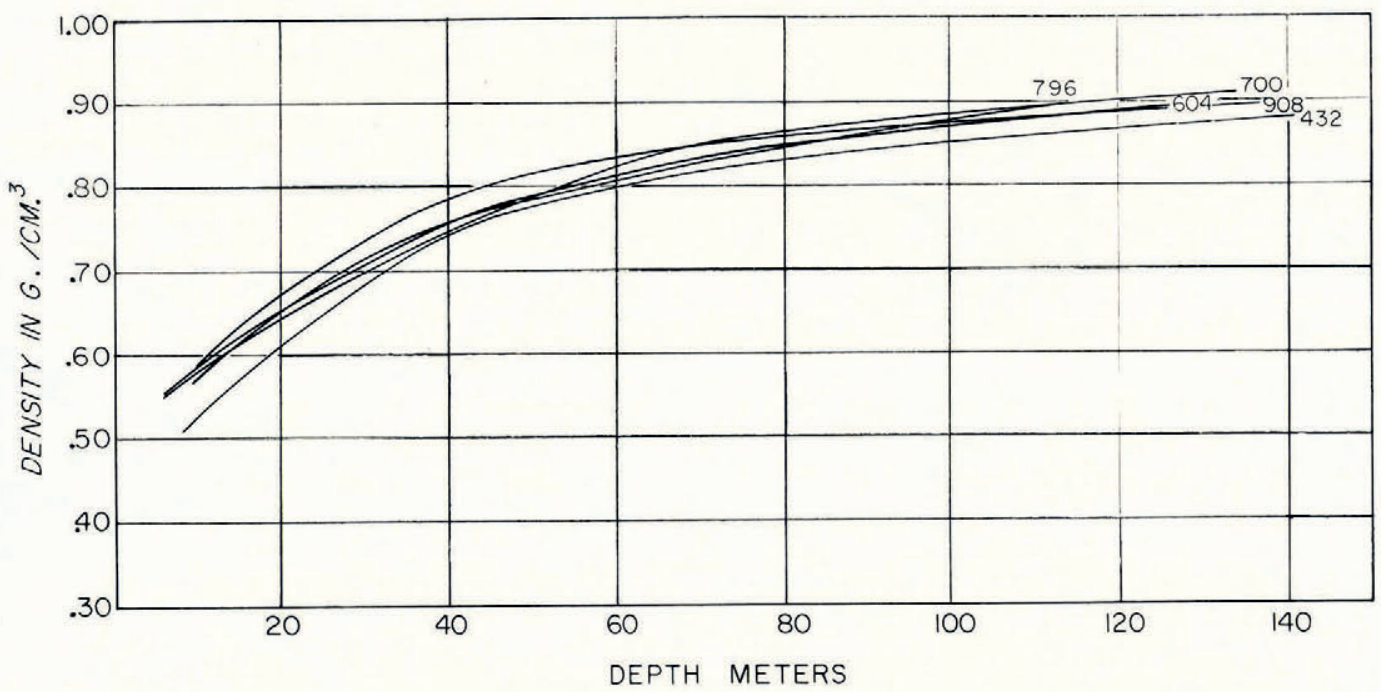

Fig. 7. Density-depth curves for 5 refraction stations extended to penetrate to depth of maximum velocity

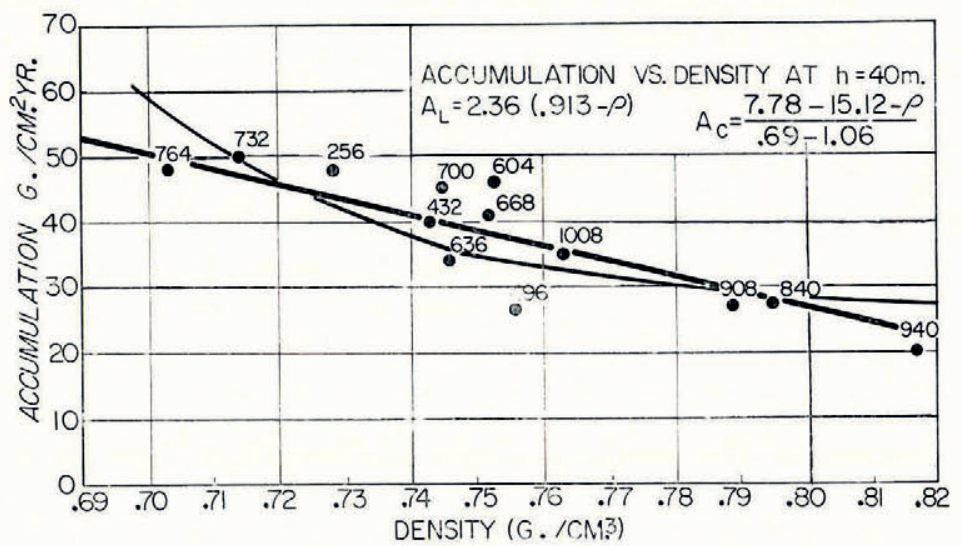

Fig. 8. Graph of accumulation vs. density at $40 \mathrm{~m}$. depth. Straight line is the least-square fit through the data; curve is determined by the expression shown 
I3. The standard deviation of points from the curve is $\pm 3 \cdot 0$ per cent and from the least-square fit of a straight line is \pm 2.7 per cent. Thus the approximation of the linear relationship

$$
\cosh \left(\sigma / \sigma_{\mathrm{o}}\right)=4 \mathrm{I} \cdot \mathrm{I} 6 \ln \rho+29 \cdot 2 \mathrm{I}
$$

has an error of \pm 3 per cent. gives:

Substituting equation (7) into equation (8) and substituting both into equation (5)

$$
0 \cdot 636-\frac{0 \cdot 69^{2}}{\rho}=\frac{c \sigma_{o}}{A}\left[55 \cdot 39-\frac{28 \cdot 4^{8}}{\rho}\right]+k \text {. }
$$

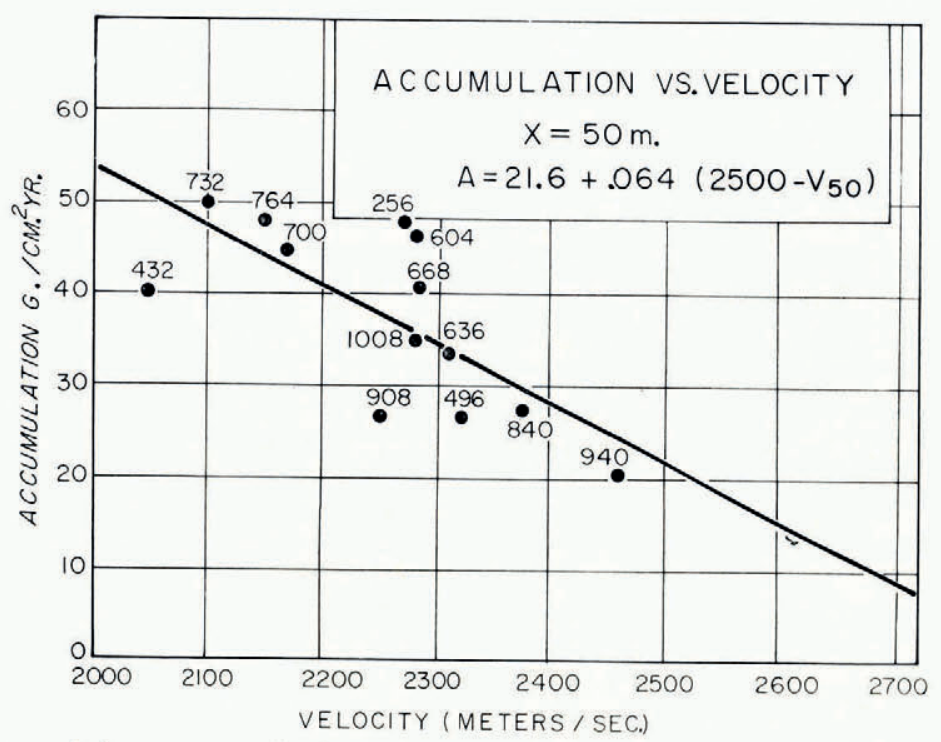

Fig. 9. Graph of accumulation vs. compressional wave velocity observed $50 \mathrm{~m}$. from the shot point. The straight line is the least-square fit to the data

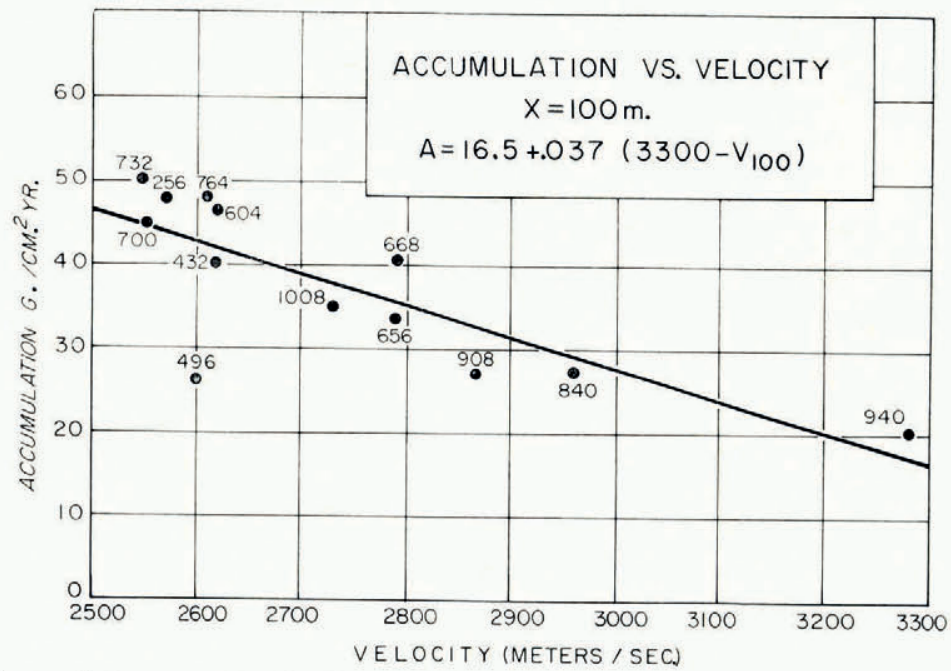

Fig. 1o. Graph of accumulation vs. compressional wave velocity observed $100 \mathrm{~m}$. from the shot point. The straight line is the least-square fit to the data 
Substituting the value of $\sigma_{0}$ and solving for $\rho$ this reduces to

$$
\rho=\frac{\left(\mathrm{I} \cdot 99 \times \mathrm{IO}^{4}\right) c-0.692 A}{\left(3.88 \times \mathrm{IO}^{4}\right) c+A(k-0.636)}
$$

with a combined error in $\rho$ of \pm 3.4 per cent where $\rho$ is in the range 0.7 to $0.8 \mathrm{~g} . / \mathrm{cm} .^{3}$. The best fit to the observed data was found to be $c=3.9 \times 10^{-4} \mathrm{yr}^{-1}$ and $k=-0.42$. These gave the expression

$$
A=\frac{7 \cdot 78-\mathrm{I} 5 \cdot \mathrm{I} 2 \rho}{0 \cdot 69-\mathrm{I} \cdot 06 \rho}
$$

from which the curve of Figure 8 was drawn. The standard deviation from the observed data

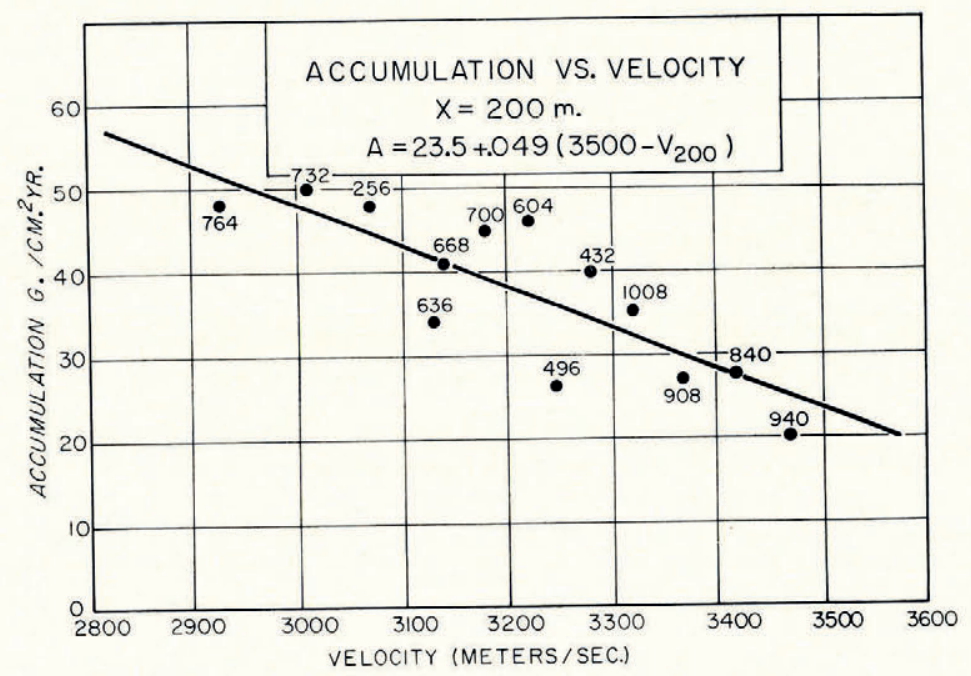

Fig. II. Graph of accumulation vs. compressional wave velocity observed $200 \mathrm{~m}$. from the shot point. The straight line is the least-square fit to the data

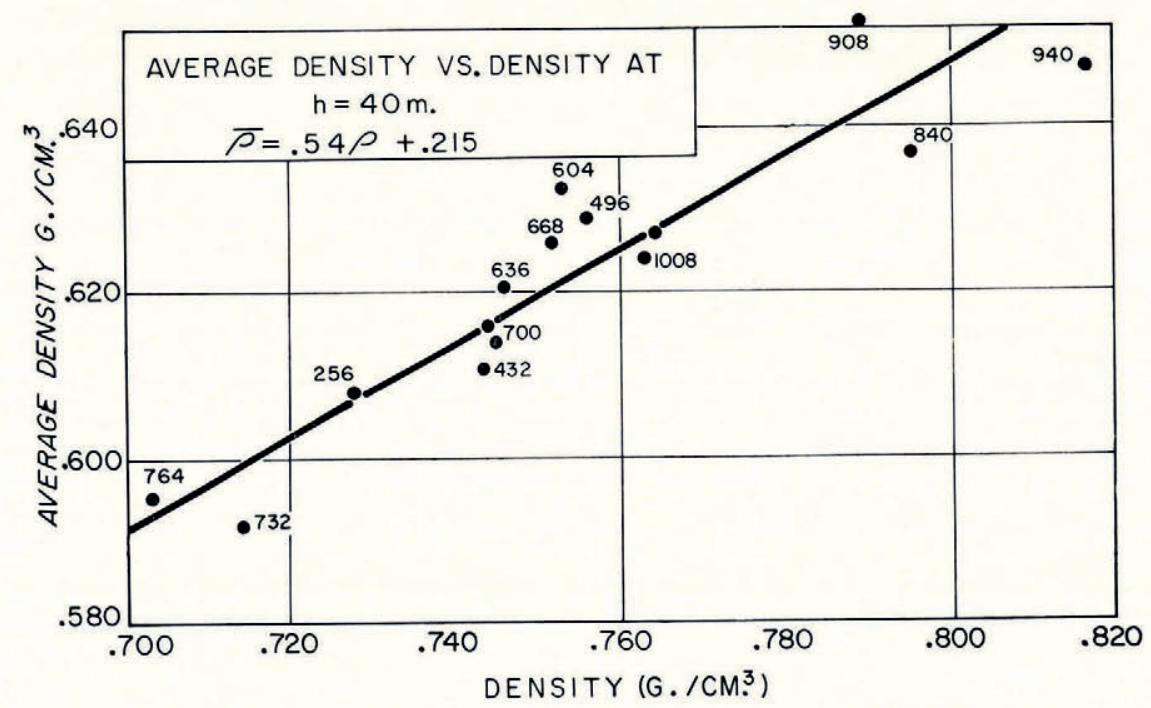

Fig. 12. Average density vs. density at $40 \mathrm{~m}$. depth. The straight line is the least-square fit to the data 
is $\pm 6 \cdot 8 \mathrm{~g} . / \mathrm{cm} .{ }^{2} \mathrm{yr}$. compared with $\pm 4 \cdot 7 \mathrm{~g} . / \mathrm{cm} .{ }^{2}$ yr. for the linear fit and $\pm 4.5 \mathrm{~g} . / \mathrm{cm} .{ }^{2} \mathrm{yr}$. from $V_{\mathrm{p}}$ at $X=200 \mathrm{~m}$. (Fig. I I). Since a number of approximations and assumptions were made in deriving equation ( $\mathrm{IO}$ ), it is not intended as a rigorous theoretical expression for the variation of density with accumulation. Rather, it allows some understanding of the empirical relations observed in Figures 8-I I.

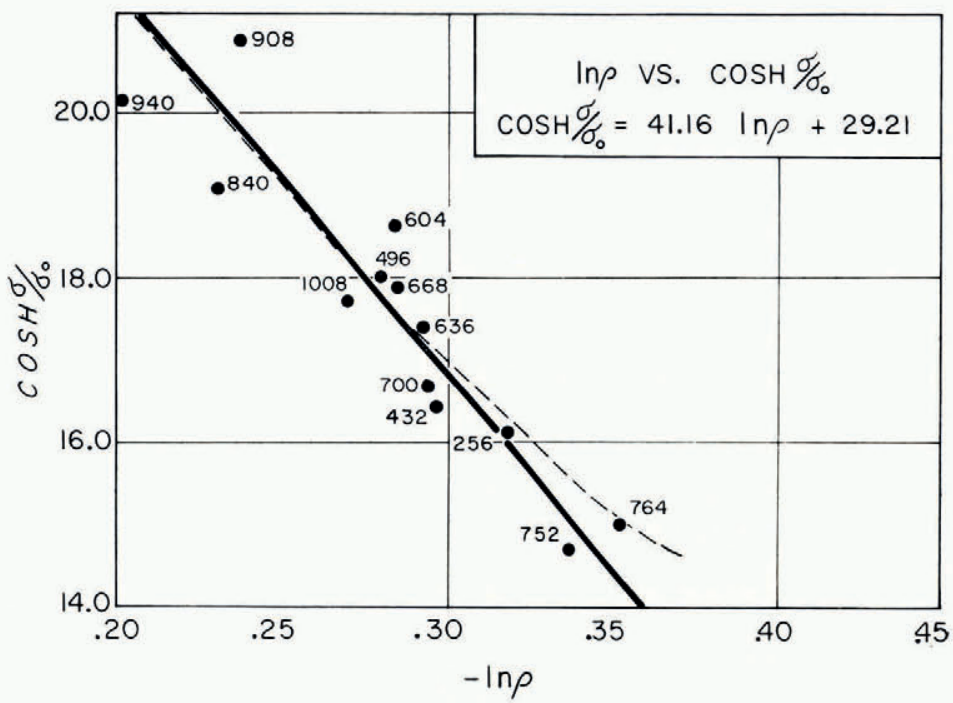

Fig. 13. Graph $\cosh \left(\sigma / \sigma_{0}\right)$ vs. $\ln \rho$. The straight line is the least-square fit to the data; the curve is the theoretical relationship

This discussion leads to the conclusion that at least in the area of the Antarctic Peninsula traverse, where the scatter in mean annual temperatures is small, the compressional wave velocity at $200 \mathrm{~m}$. distance from the shot point or the density at $40 \mathrm{~m}$. depth can be used to obtain reasonably reliable values of accumulation. The graph of accumulation versus velocity at $200 \mathrm{~m}$. is preferred over the graph of accumulation versus density because it is much less time-consuming to determine a velocity (which can be taken directly from a seismogram) at a given distance than a density at a specific depth.

Determinations of the accumulation were made for all of the seismic stations as shown in Table I using Figures 8 and I I. $A_{\mathrm{L}}$ and $A_{\mathrm{C}}$ refer to values from the straight line and curve of Figure $8 ; A_{\mathrm{v}}$ refers to the values from $V_{\mathrm{p}}$ at $X=200 \mathrm{~m}$. The standard deviation is $\pm 2 \cdot 9$ g. $/ \mathrm{cm} .^{2} \mathrm{yr}$. for the comparison of the three methods. This should be regarded as an indication of the internal agreement of the data rather than an indication of absolute accuracy of the accumulation values.

\section{Acknowledgements}

This work was conducted while the author was employed at the Geophysical and Polar Research Center at the University of Wisconsin and was supported by a grant from the National Science Foundation. I would like to thank C. R. Bentley for many helpful suggestions in the course of this study. This discussion, together with the velocity-distance-depth data, is included in Geophysical and Polar Research Center Report 64-I.

MS. received 26 May 1964 


\section{REFERENCES}

Bader, H. 1962. The theory of densification of snow on high polar glaciers. U.S. Cold Regions Research and Engineering Laboratory. Research Report 108.

Behrendt, J. C. 1963. Seismic measurements on the ice sheet of the Antarctic Peninsula. Journal of Geophysical Research, Vol. 68, No. 21, p. 5973-9o.

Landauer, J. K. 1957. Creep of snow under combined stress. U.S. Snow, Ice and Permafrost Research Establishment. Research Report $4 \mathrm{I}$.

Robin, G. de Q. 1958. Glaciology. III. Seismic shooting and related investigations. Norwegian-British-Swedish Antarctic Expedition, 1949-52. Scientific Results (Oslo, Norsk Polarinstitutt), Vol. 5.

Slichter, L. B. 1932. The theory of the interpretation of seismic travel-time curves in horizontal structures. Physics, Vol. 3, No. 6, p. 273-95. 